Volume 12

Issue 2 Images And Collective Violence:

Function, Use And Memory

Article 15

$10-2018$

\title{
Book Review: Genocide: A World History
}

Renato S. Bahia

Aberystwyth University

Follow this and additional works at: https://digitalcommons.usf.edu/gsp

\section{Recommended Citation}

Bahia, Renato S. (2018) "Book Review: Genocide: A World History," Genocide Studies and Prevention: An International Journal: Vol. 12: Iss. 2: 190-192.

DOI:

https://doi.org/10.5038/1911-9933.12.2.1558

Available at: https://digitalcommons.usf.edu/gsp/vol12/iss2/15

This Book Review is brought to you for free and open access by the Open Access Journals at Digital Commons @ University of South Florida. It has been accepted for inclusion in Genocide Studies and Prevention: An International Journal by an authorized editor of Digital Commons @ University of South Florida. For more information, please contact digitalcommons@usf.edu. 
Book Review: Genocide: A World History

\author{
Renato S. Bahia \\ Aberystwyth University \\ Aberystwyth, Wales, United Kingdom
}

Genocide: A World History

Norman M. Naimark

New York, Oxford University Press, 2017

178 pages; Price: $\$ 19.95$ paperback

Reviewed by Renato S. Bahia

Aberystwyth University

Norman Naimark is well known for his rich work on Eastern European history and on Soviet/ Russian politics. Since the wars in the Balkans in the 90's, his interest has shifted towards genocide studies and mass atrocities, especially with the publication of Fires of Hatred, ${ }^{1}$ where the author questioned the possibilities of novelty and of repetition within twentieth century European history in terms of ethnic killings. In Genocide: A World History, the author in many ways tries to broaden the horizons of mass atrocities, albeit focused on the phenomenon of genocide, throughout a somewhat large scale comparative study of different spatial-temporal circumstances where one can argue that genocide took place.

In a broader scale, the main problem that the book attempts to tackle would be a question of the definition of genocide. That is, how certain modern approaches of what genocide is might limit the scope and possibilities of understanding, of delimiting, not only comparative studies of genocide cases, but the very possibilities of branding a certain situation as genocide. Particularly, Naimark seems to be concerned with how we might go on about avoiding a modernist and therefore limited definition of genocide. By "modernist" definition, I refer here to what Naimark calls an unjust privilege of the "modern" take on what genocide is, an approach that discounts the possibilities for a longue durée of the idea of genocide. ${ }^{2}$

Thus, in many ways Genocide: A World History can be seen as a continuation of sorts with Raphael Lemkin's uncompleted task of writing down an international history of genocide that would range from the most ancient cases-such as Biblical narratives of genocide, Carthage and so forth - to the most recent ones, passing through medieval crusades, the bloody conquest of the New World, colonial genocidal campaigns and, finally, twentieth century cultural, political, and ethnical genocides. Or, in the author's words "this book also assumes that genocide is a worldwide historical phenomenon that originates with the beginning of human society." ${ }^{3}$

In terms of definitions Naimark concedes to what he calls "the fundamental definition accepted by scholars and the international courts in their work on genocide both past and present," 4 that is, the genocide convention. With a few caveats he purposely considers cultural and political groups within the range of possibilities for genocide-since that would be Lemkin's original intentionwhile also claiming to focus on what he calls the 'evolution of the term,' i.e., the jurisprudence from recent International Tribunals that have been focusing on the centrality of mass killings in evaluating a case where genocide is recognized to have happened. ${ }^{5}$

Thus, the definition is broad enough to consider the intended longue durée of the idea of genocide, that is, what sort of actions one might englut in order to understand the history of such a phenomenon in a way that goes beyond modern frames that might limit not only visions and ideas of a "typical genocide case" - whatever that may be-but, sociologically perhaps, also in

${ }^{1}$ Norman M. Naimark, Fires of Hatred: Ethnic Cleansing in Twentieth-Century Europe (Cambridge: Harvard University Press, 2002).

${ }^{2}$ Norman M. Naimark, Genocide: A World History (Oxford: Oxford University Press, 2017), 142.

${ }^{3}$ Naimark, Genocide, 5 .

${ }^{4} \mathrm{Ibid} ., 3$.

${ }^{5}$ Ibid.,4.

Renato S. Bahia. "Book Review: Genocide: A World History" Genocide Studies and Prevention 12, 2 (2018): 190-192. @2018 Genocide Studies and Prevention.

https://doi.org/10.5038/1911-9933.12.2.1558 
terms of possibilities to prevention. Not that the author engages in specific formulae to prevent genocide, but as not only he mentioned, and as is well accepted throughout the social sciences, ${ }^{6}$ understanding its history can only help us get to a possibility of a solution to the problem at hand. ${ }^{7}$

But it is also narrow enough so as one can still attempt to grasp what a general idea of genocide might consist of throughout such an extensive chronology. In other words, and to cite a relatively recent autobiography of Lemkin, "A line, red from blood, led from the Roman arena through the gallows of France to the pogrom of Bialystok." 8 Throughout the chronology of Naimark's book, one can come to terms not only of what that line red from blood running through history might mean, but also in its implications. That is to appreciate when and where genocide might occur, or even is occurring, one needs to get rid of a very liberal notion that genocide usually only happens in totalitarian states or, in the very least, non-liberal democratic ones. ${ }^{9}$ Or, in another vein, that genocide comes exclusively as the other side of modernity's promises of progress, ${ }^{10}$ or even that it essentially originates from modern revolutionary-and sometimes racial-movements. ${ }^{11}$

One must add, not only this 'line red from blood' is well written out throughout the book, but also each chapter is extremely clear in showing where one might find the arguments and similarities in terms of the author's notion of what genocide consists of, and where such similarities might fall short. In ancient genocides, for instance, the author duly recognizes how distant "salting of the earth," "concubines," "taking of slaves," "sacrifice to the gods [and God]" might sound to modern ears, but also how the killing was essentially, "intentional, total and eliminationist." ${ }^{12}$ Genocide as a concept, per se, might not be there, but essentially the core of what the idea represents can be seen as representatives, as attempts of making sense, of what the historical narratives calls forth.

While, on the one hand, the argument seems to take a stretch when talking about the Mongols as Genocidaires in the strict sense-as suggested by Naimark himself when stated that "Some commentators find it difficult to classify the Mongol killing as genocide." ${ }^{13}$ On the other hand, one has to appreciate that the inclusion of medieval cases - such as the crusades in the Near East against the Cathars and, eventually, the Mongols themselves - might help the understanding of a few possible origins and, perhaps, justifications, for the well-researched, but no less controversial cases of colonialism as genocide. If the partial goal of the book is to understand the crime of genocide from broader lenses than modernity as a main, if not sole, culprit, then this chapter represents an important step in what one may understand as a longue durée of genocide, i.e., as one specific temporal dimension of the idea of genocide that detaches but also takes part in the long term of what such an idea, if not concept, might represent. This constant transformation, with the addition of different layers to possibilities of meanings to genocide-or, in other words, what sort of actions, intentions, deeds may be included in a general idea of genocide-is also seen in the following chapter, when Naimark covers genocide in the Spanish conquest of the New World. One can see, or so is claimed, both renditions of past experiences in the form of a sort of crusading spirit of the conquerors and the newer racial nuances that such actions also entailed. ${ }^{14}$ The line, red from blood, keeps on running, zig-zagging back and forth between certain ideas, characterizations, possibilities, in such a way that the book's narrative becomes enabled.

\footnotetext{
${ }^{6}$ Martin Shaw, What is Genocide?, 2 ${ }^{\text {nd }}$ ed. (Cambridge: Polity Press, 2015), 1-2.

${ }^{7}$ Naimark, Genocide, 144.

${ }^{8}$ Raphael Lemkin, Totally Unofficial: The Autobiography of Raphael Lemkin, ed. Donna-Lee Frieze (New Haven: Yale University Press, 2013), 17.

${ }^{9}$ A. Dirk Moses, "Toward a Critical Theory of Genocide", Online Encyclopedia of Mass Violence (April 18, 2008), http:// www.sciencespo.fr/mass-violence-war-massacre-resistance/en/document/toward-theory-critical-genocide-studies.

${ }^{10}$ While Bauman's argument towards a non-exclusivist approach towards the Holocaust in terms of genocide, it is, nevertheless, necessary to stress how still limiting the demarcation "Modernity-Genocide" might be. See further Zygmunt Bauman. Modernity and the Holocaust (Ithaca, N.Y.: Cornell University Press, 1989).

${ }^{11}$ Eric D. Weitz, "The Modernity of Genocides: War, Race, and Revolution in the Twentieth Century" in The Specter of Genocide: Mass Murder in Historical Perspective, ed. Robert Gellately and Ben Kiernan (New York: Cambridge University Press, 2003), 53-73.

${ }^{12}$ Naimark, Genocide, 14.

${ }^{13}$ Ibid., 33.

${ }^{14}$ Naimark, Genocide, 47.
} 
Thus, more than an outright book about who did what, when, and against whom, that is, more than an analysis that covers essentially a "tidely organized drama of passive victims, wicked perpetrators, and craven bystanders," 15 Genocide: A World History puts forth an important claim towards the understanding of what genocide is supposed to represent in time and in space. In other words, even if the author's conceptual basis lies in the Genocide Convention, recent jurisprudence on the matter and Lemkin's original intention, to be able to surmount an understanding of the concept of genocide in the longue durée, requires a recognition of the different spatial-temporal conditions of each case, even if the author is essentially looking broadly, almost skimming, through the cases. In other words, the way each case and situation is explored goes beyond the common understanding of genocide as an end-point of sorts and more as a means to different forms of ends that such a lengthy spam of perpetrators might have.

To be fair, to point the case studies as almost skimming through them is more a statement than a criticism per se. After all, perhaps one of the great commendations of this work is its name choice-Genocide, $a$ World History. I would like to stress the importance for the argument of the book, of the "a" as in delimiting that the present narrative is not, could not, claims not to be final. This is what the book does, and does well at that-building one possible, perhaps grand, narrative of what genocide in the long run can be. In the end, even if the author makes no claims towards strictly resolving the genocide issue, it contributes well in its consideration of genocide beyond, but not ignoring, International Tribunals and courts of Justice as if the law, by itself, held the (only) key to the issue.

However, perhaps one of the main flaws of the book concerns its theoretical background, especially in relation to its intended audience. While to claim for a longue durée of genocide, a process that is interestingly shown throughout the chapters, one still may find oneself in the dark if unfamiliar with what such a claim might bring. Although it has hints throughout the book, it is only once that the term, longue durée, appears briefly in the conclusion, ${ }^{16}$ which prompts an almost sigh of understanding on the reader in terms of what the book could possibly be about. Yet, as the author suggested in an interview, ${ }^{17}$ if the book is directed mostly to, and made from, his graduate students (questions in classes), one has to wonder if it would not have been useful to elaborate a bit more on the theoretical point that the book brings about, its implications, and its consequences, its limits and insights. In the end, Genocide: A World History is a welcome sight for undergraduate and graduate level students that seeks to jump into the field of genocide studies, while still offering some interesting points towards more experienced scholars and the field as a whole.

\footnotetext{
${ }^{15}$ A. Dirk Moses, "Empire, Colony, Genocide: Keywords and the Philosophy of History", in Empire, Colony, Genocide: Conquest, Occupation, and Subaltern Resistance in World History, ed. A. Dirk Moses (New York: Berghahn Books, 2008$), 6$. ${ }^{16}$ Naimark, Genocide, 142.

${ }^{17}$ Norman Naimark, "Q\&A with Professor Naimark on the History of Genocide", Stanford Global Studies, December 8, 2016, https://sgs.stanford.edu/news/qa-professor-naimark-history-genocide.
} 